\title{
Addictive Shopping Behaviour of Indian Women - A Theoretical Aspect (With Special Reference to Apparel and Jewellery Shopping)
}

\author{
Shweta Uniyal*, Dr P. K. Sharma ** \\ * (Research Scholar, Banasthali Vidhyapith, Rajasthan) \\ ** (Professor, V. M Open University Kota)
}

\begin{abstract}
Women and their association with shopping are inseparable. Due to changing lifestyle, market culture, shopping habits, market awareness, women empowerment and economic freedom - women are becoming a consistent customer but sometimes this overwhelming urge leads to shopping addiction. In India shopping addiction is still a new disorder which is still unexplored. This paper will explore more about shopping addiction and different aspects of it. This paper willfind out various reasons for addictive shopping and also discover the reasons for post regrets
\end{abstract}

Keywords: Addictive Shopping, Post Regrets, Reasons, Women

\section{Introduction}

Addictive shopping is on increase. It is an extreme form of consumer behaviour but it has not studied properly. Feeling of great expectation and excitement prior to and during the shopping experience are replaced by guilt and shame afterwards. Addictive consumers buy for motives unrelated to the actual possession of apparels and most purchases remain unused. India is a developing country but still there are strata of women from middle and high class income group who do addictive shopping. These women later on regrets on what they had purchased. The basic reason for this is changing shopping environment in India and also the role of women. Indian women traditionally used to confine themselves to households activities. Today women are no longer just a gatekeeper of the family. They have got more empowerment and economic freedom. This is why their shopping habits have changed. Also there has been a change in traditional way of thinking in the society. Even marketers are waking up to the vast purchasing power of the female market. Toknow addictive shopping more, one should have an idea about the difference between buying and shopping: normal shopping and addictive shopping: buying process and addictive shopping process.

Buying is a need based activity. The persons buy only what they need. Shopping is the examining of goods or services from retailers with the intent to purchase at that time.

Shopping is an activity of selection and/or purchase. Normal shopping is always within the limitations. It never leads person to unnecessary and unmanageable debts whereas Addictive Shopping is continuous and excessive in nature. It lacks rationalization and can leads person to various troubles.

Buying process is a time bound process in which there is a rational approach by the buyer. It has stages like need recognition, information search, and evaluation of alternatives, selection and post purchase. Whereas, addictive shopping lacks rationalization.It is unplanned and continuous.

\section{Different Aspects of Addictive Shopping:}

Addictive shopping can be analysed by three aspects:

\section{Perspective of Addictive Shoppers:}

Addictive shopping is the extreme form of consumer behaviour which is relatively untapped. An extreme of anything is bad and same goes with addictive shopping also. The following points will describe the prospective of addicted shoppers.

- Addictive shoppers don't live in real world; they have got their own virtual world. While shopping they don't remember who they are; they simply are transformed to who they want to become.

- The addicted shopper buys product for no cause; they neither value it nor desire. Sometimes the products purchased remain unopened and hence unused.

- The consequences of it are unfavourable to the individuals and cause regrets. Addictive shoppers sometimes are not able to pay their bills which can lead them to unmanageable debts and may have legal problems. 


\section{Perspective of Marketers:}

Speaking about shopping and not mentioning the marketers would be somewhat unfair. Marketers are the people who promote or exchanges goods or services for money. The following points will describe the perspective of marketers in respect with shopping addiction.

- The prime objective of every business is to increase sales and earn huge profits. For that marketers apply all the tactics at their best. They spend enormous amount on promotion campaign and on all the push strategies.

- On the darker side of addictive shopping and its encouragement through promotion to an extreme, the shoppers have to face some serious problems which cause discomfort, worry and grief. It could be further explained by utilitarianism ethical approach.

The utilitarianism ethical approach was originally developed by the English philosopher and social reformer Jeremy Bentham. It suggests that an action is right if, and only if, it conforms to the principle of utility, whereby utility is maximized (i.e. pleasure, happiness or welfare) - and pain or unhappiness minimized - more than any alternative. This approach says- if any business action causes pain or unhappiness that action would not be considered as ethical. For example: Cigarette companies always want people to be addicted to it. But in this age of corporate social responsibility, they can't ignore their obligation. For that reason they have to mention "cigarette smoking is injurious to health - it causes cancer".Above all due to CSR they have to check their promotion strategies also. Same goes for addictive shopping, when marketers know about its bad consequences they should understand their responsibility towards shoppers and society and take essential corrective action.

- In addictive shopping most of the purchased items remain unused and later on become the cause for the regrets. This is so serious that it can even lead to market failure. According to marketing, customers are those who purchase the product and consumers are those who use it. As product in addictive shopping remains unused then in this case shoppers stay as customers never turn into a consumer. Addictive shoppers will purchase the commodity again for sure but maybe they not repeat the brand. This may lead problem for the marketers in long run.

\section{Perspective of Society:}

Marketing plays an important role in developing and transforming society. It has its affects in everyone's life. Like any other addiction, shopping addiction is also not beneficial for society. It has several bad consequences which can ruin the society as a whole. Addictive shopping or spending may result in interpersonal, occupational, family and financial problems in one's life. In addition to it we can mention that, excess of anything is always bad. Same goes for marketing and shopping. Excessive marketing leads to excessive shopping which leads to excessive problems and cause harm to the society. In other words: we are buying far too much and marketing is to be blamed for it. In sum, addictive shopping can result in emotional distress, broken families and market failure. In concern with society there should be a check on shopping addiction, people should understand its importance and take necessary corrective actions.

\section{Reasons For Addictive Shopping}

Shopping addictive women as they enter malls, shops, departmental stores etc. they do excessive shopping, and the reasons for that could be:

- There is continuous change in India's environment, these growing changes bring social and economic variations on different aspects of our daily life and hence contribute to addictive shopping behaviour of women.

- Now women are independent and educated. They are more aware and informed. As they work and they do have money. When one has money then it is easy to spend. But that spending is not wiser, hence it causes regrets.

- The other reasons could be increase in family income, availability of variety of goods, discounts and offers on sales, multiple shopping channels etc. Indian women also get influenced by others be it their friends, relatives, peer groups, neighbours; or even they compare themselves with different celebrities. All these reason tend towards addictive shopping.

- Women consider shopping as mood buster. When they are not able to stand negative feelings, pain, loneliness, boredom, depression, fear, anger they go for shopping and this is how they boost up their mood.

- Addictive shoppers live in a virtual world of their own; they forget what they are, what is their income level etc. They just become who they would like to be. This is again a reason for addictive shopping

When any of these reasons crop up, then addictive shopper crave for shopping.

\section{Reasons For Post Regrets}

A negative outcome of addictive shopping is that it leads to Post Regrets.The basic reason for their regret is the apparel and jewellery they had purchased remains unused. The Addictive shopper purchase 
unreasonably which leads to unmanageable debt levels. They purchase to such an extent that they run their credit cards up to the limit. This will lead shopper into financial crises which cause tension, frustration and guilt and hence create regretsThe personal life of addictive shopper get affected by addictive shopping. Addictive shopping can result in emotional distress and broken families. Addictive shoppers in extreme case lie about their shopping habit and also sometimes hide their purchased products which will leads to post regrets.

\section{Conclusion}

From the study it can be concluded that Addictive Shopping is on increase and is an extreme form of consumer behaviour.Today women are no longer just a gatekeeper of the family. They have got more empowerment and economic freedom. This is why their shopping habits have changed. This study also emphasis on different reasons for addictive shopping. Change in India's market environment, availability of variety of goods, discounts and offers on sales, multiple shopping channels etc. considered as some of the reasons for addictive shopping. Today women are more independent and educated. They are more aware and informed. They work and they do have money, all these factors push them for shopping. But this non rational shopping leads to post regrets also. This study conclude on a note that everything is changing and so does our shopping pattern. Excessive marketing is leading women in to addictive shopping and its post regrets.

\section{References}

[1]. Alice Hanley and Mari S.Wilhelm (1992), "Compulsive Buying: An Exploration into Self-Esteem and Money Attitudes", Journal of Economic Psychology, pp 135-18

[2]. Aviv Shoham and Maja MakovecBrencic (2003), “Compulsive Buying Behaviour”,Journal of Consumer Marketing, Vol 20 , No.2. pp 127-138

[3]. Cobb, C.J., Hoyer, W.D. (1986), "Planned versus impulse purchase behavior", Journal of Retailing, Vol. 62 pp.384-409.

[4]. Dr.Mu.Subrahmanian(2011), "Buying Behavior of the New Aged Indian Women", Indian Journal of Commerce \& Management Studies Vol No. 2, Issue No. 5, pp 143-148

\section{Web Links}

http://www.askmikethecounselor2.com/shopping-addiction.html http://addictions.about.com/od/lesserknownaddictions/a/shoppingadd.htm http://www.addictionrecov.org/Addictions/index.aspx?AID=34 http://www.addictionhelpcenter.com/causes-for-compulsive-shopping http://amolife.com/psychology/emotional-shopping-addiction-10-tips-that-will-help-you-to-stop.html 